Pendas : Jurnal IImiah Pendidikan Dasar, ISSN Cetak : 2477-2143 ISSN Online : 2548-6950 Volume II Nomor 2, Desember 2017

\title{
BUKU AJAR MEMBACA DAN MENULIS PERMULAAN DENGAN METODE IQRO UNTUK SISWA KELAS I SEKOLAH DASAR: TEMATIK IPA, IPS, DAN KESENIAN
}

\author{
Supriyadi \\ Pendidikan Bahasa Indonesia, FKIP, Universitas Sriwijaya \\ supri_unsri@yahoo.com \\ Asnimar \\ PGSD, FKIP, Universitas Sriwijaya \\ imar56unsri@gmail.com \\ Marwan Pulungan \\ PGSD, FKIP, Universitas Sriwijaya \\ marwan_pulungan@gmail.com
}

\begin{abstract}
This study was aimed at producing pre-reading and writing textbooks that use the thematic lqro method in IPA, IPS, and art subjects. The development research is used with the steps of: initial studies, development, evaluation/ revision, limited trials, and evaluation/revision. Preliminary studies include curriculum analysis, existing textbooks, and demand analysis based on questionnaires and interviews developed. The development stage includes the design of themes and subthemes, the framework of the book content, and the development of the initial draft of the book as a prototype I. The evaluation stage includes expert validation and limited testing. The results of preliminary studies show that in South Sumatra there is no beginning reading and writing textbook that meets the principles of Iqro and thematic methods. The results of questionnaires and interviews indicate that teachers have difficulty using the Diknas package because many students can not $\mathrm{read} / \mathrm{write}$ so that books are needed that can accelerate the reading and writing ability of the first grade students demanded by the Curriculum 2013. Based on preliminary studies, and subthemes, the framework of the contents of the book, and the early drafts of textbooks developed based on the principles of lqro method that have been themically modified by Science, Social Studies, and the arts. Subsequently validated by two experts. From the results of validation, the textbook was revised based on validator input that is by adding interesting pictures and instructions for clear teachers and students. The result of the textbook revision was tested in limited in two elementary schools. The test results show, textbooks with the method of Reading and Writing lqro Modifikasi significant effect on learning to read and write the beginning in grade 1 primary school.
\end{abstract}

Keywords: Read and write start, lqro method and Thematic. 


\section{ABSTRAK}

Penelitian ini bertujuan untuk menghasilkan buku ajar membaca dan menulis permulaan yang menggunakan metode lqro yang tematik dalam topik IPA, IPS, dan kesenian. Penelitian pengembangan digunakan dengan langkah-langkah: studi awal, pengembangan, evaluasi/ revisi, uji coba terbatas, dan evaluasi/revisi. Studi awal meliputi analisis kurikulum, buku teks yang ada, dan analisis kebutuhan berdasarkan angket dan wawancara yang dikembangkan. Tahap pengembangan meliputi perancangan tema dan subtema, kerangka isi buku, dan pengembangan draf awal buku sebagai prototipe I. Tahap evaluasi meliputi validasi ahli dan uji coba terbatas. Hasil studi awal menunjukkan bahwa di Sumatera Selatan belum ada buku pelajaran membaca dan menulis permulaan yang memenuhi prinsip metode lqro dan tematik. Hasil angket dan wawancara menunjukkan bahwa guru mengalami kesulitan menggunakan buku paket Diknas karena banyak siswa yang belum bisa membaca/menulis sehingga diperlukan buku yang dapat mempercepat kemampuan membaca dan menulis siswa kelas I SD yang dituntut oleh Kurikulum 2013. Berdasarkan studi awal, dirancang tema dan subtema, kerangka isi buku, dan draf awal buku ajar yang dikembangkan berdasarkan prinsip-prinsip metode lqro yang telah dimodifikasi secara tematik IPA, IPS, kesenian. Selanjutnya divalidasi oleh dua orang ahli. Dari hasil validasi, buku ajar direvisi berdasarkan masukan validator yaitu dengan menambahkan gambar yang menarik serta perintah bagi guru dan siswa yang jelas. Hasil revisi buku ajar tersebut diujicobakan secara terbatas di dua SD. Hasil ujicoba menunjukkan, buku ajar dengan metode Membaca dan Menulis lqro Modifikasi berpengaruh signifikan terhadap pembelajaran membaca dan menulis permulaan di kelas 1 sekolah dasar.

Kata Kunci: Membaca dan menulis permulaan, Metode iqro dan Tematik

\section{A. Pendahuluan}

Sekolah Dasar (SD) 6 tahun sebagai bagian dari pendidikan dasar 9 tahun merupakan lembaga pendidikan pertama yang menekankan siswa belajar membaca, menulis, dan berhitung (calistung). Ketiga kecakapan ini merupakan landasan, wahana, dan syarat bagi siswa untuk belajar menggali dan menimba ilmu pengetahuan lebih lanjut. Oleh karena itu, penguasaan ketiga keterampilan ter- sebut perlu dipertahankan dan ditingkatkan (Depdikbud, 1991/1992:iv).

Membaca dan menulis permulaan merupakan keterampilan berbahasa yang harus dikuasai siswa sejak kelas rendah/ awal sekolah dasar.Tanpa penguasaan kedua keterampilan berbahasa tersebut, siswa akan kesulitan dalam seluruh mata pelajaran. Bahkan tanpa penguasaan kedua keterampilan berbahasa tersebut, guru tidak akan menaikkan siswa ke ke las yang lebih tinggi. Oleh sebab 
itu penguasaan kedua keterampilan ini mutlak diupayakan guru sejak siswa kelas 1 sekolah dasar.

Belajar membaca dan menulis bagi siswa kelas 1 sekolah dasar, bukan di taman kanak-kanak (TK) merupakan tugas guru yang sangat utama dan strategis. Dalam kenyataan masih banyak siswa kelas tinggi, yakni kelas 3 -- 6 SD, bahkan beberapa siswa kelas 1 SMP belum lancar membaca (Hasil pengamatan ketika penjadi pembimbing PPL dan wawancara dengan guru peserta PLPG). Sebenarnya banyak metode membaca dan menulis permulaan yang dapat dipilih dan digunakan guru kelas 1 agar siswa dapat dengan cepat menguasai kedua keterampilan ini. Terdapat metode membaca dan menulis permulaan seperti: metode abjad, eja, kata lembaga, SAS, iqro modifikasi yang dapat digunakan guru. Dalam kenyatannya para guru sering mengalami kesulitan menerapkan metode membaca dan menulis tersebut karena sangat sedikitnya buku ajar yang mengimplementasikan metode tersebut secara sistematis. Namun para guru tetap berusaha untuk mereka-reka sendiri agar siswa dapat belajar membaca dan menulis walaupun hasil yang diperoleh belum optimal.

Buku ajar yang mengimplementasikan metode membaca dan menulis permulaan tersebut sangat sedikit. Balai Pustaka pernah menerbitkan buku Pandai Membaca dan Menulis 1a,1994 menggunakan metode SAS, sebagai buku wajib (buku droping), hasilnya cukup memuaskan. Namun buku tersebut tidak banyak digunakan lagi oleh guru kelas 1 dengan berbagai alasan. Berdasarkan pengamatan, banyak buku yang digunakan guru di kelas 1 sekolah dasar kurang sesuai dengan teori pembelajaran membaca dan menulis permulaan, namun buku tersebut tetap digunakan karena mempunyai manfaat finansial yang lumayan bagi guru dan kepala sekolah. Termasuk buku paket kurikulum KTSP dan Kurikulum 2013 (K13) tidak jelas metode dalam pembelajaran membaca dan menulis permulaan.

Terdapat buku ajar membaca dan menulis permulaan dengan menggunakan metode iqro modifikasi, dalam pembelajaran membaca dan menulis (Supriyadi, 1997) yang beredar secara terbatas di Provinsi Sumatera Selatan dan Bangka- 
Belitung. Buku tersebut sudah banyak digunakan oleh guru-guru sekolah dasar yang pernah mengikuti seminar, pelatihan di LPMP Sumsel, dan PLPG di Rayon 104 Univeritas Sriwijaya, secara terbatas karena buku tersebut belum diterbitkan. Hasil pembelajaran dengan buku tersebut sangat menggembirakan karena ratarata 1 semester (lebih kurang 4 bulan) siswa kelas 1 sudah lancar membaca dan menulis, (Hasil wawancara dengan guru dan hasil penelitian). Namun kekurangan buku tersebut pada materi yang digunakan sebagai wacana belum tematik dengan pelajaran lain, seperti: IPA, IPS, Kesenian, dan matematika sehingga para guru kesulitan mengintegrasikan dengan pelajaran tersebut dalam membuat RPP. Pada akhirnya para guru pengguna buku tersebut meninggalkan buku ajar iqro modifikasi karena pemerintah mewajibkan guru kelas rendah SD mengajar secara tematik.

Pembelajaran tematik bagi sebagian besar guru kelas rendah merupakan tugas yang sangat berat, terutama karena belum ada buku/bahan ajar yang tematik (Hasil wawancara dengan peserta PLPG). Landasan yuridis yang mengatur pelaksanaan pembelajaran tematik di sekolah dasar yaitu Peraturan menteri Pendidikan Nasional Republik Indonesia Nomor 22 tahun 2006 tentang standar isi, nomor 23 tahun 2006 tentang standar kompetensi lulusan, dan nomor 24 tahun 2006 tentang pemberlakuan Permendiknas no 22 dan 23 tahun 2006.

Berdasarkan Puskur, pembelajaran tematik di sekolah dasar memiliki ciri-ciri sebagai berikut. (1) Berpusat pada siswa; (2) Memberikan pengalaman langsung; (3) Pemisahan mata pelajaran tidak begitu jelas; (4) Menyajikan konsep dari berbagai pelajaran; (5) Bersifat fleksibel; (6) Hasil pembelajaran sesuai dengan minat dan kebutuhan siswa; dan (7) Menggunakan prinsip belajar sambil bermain dan menyenangkan.

Broughton, et al. (1978:211) mengatakan bahwa membaca permulaan adalah proses pengenalan lambang bunyi bahasa dalam bentuk huruf dan tanda baca, hubungan timbal balik antara lambang bunyi dengan unsur-unsur linguistik dan hubungan lambang bunyi, unsur linguistik dengan makna. Ketiga komponen itu disebut keterampilan mekanikal (mechanical skills). Sementara itu Downing (1982: 206) mengatakan bahwa membaca 
Pendas : Jurnal IImiah Pendidikan Dasar, ISSN Cetak : 2477-2143 ISSN Online : 2548-6950 Volume II Nomor 2, Desember 2017

permulaan adalah proses menerjemahkan simbol-simbol bahasa tulis ke dalam bunyi.

Batasan yang dikemukakan di atas, pada hakikatnya menekankan bahwa membaca permulaan adalah kegiatan awal belajar membaca.Pada tahap ini pembaca belum memiliki keterampilan membaca yang sesungguhnya, tetapi masih dalam tahap belajar untuk memperoleh keterampilan membaca yang sesungguhnya (membaca pemahaman).

Gibson \& Levin dalam Downing (1982) menjelaskan bahwa untuk memperoleh kemampuan membaca diperlukan 3 syarat yaitu (1) kemampuan membunyikan lambang-lambang tulis, (2) penguasaan kosa kata untuk memberi arti, dan (3) memasukkan makna dalam kemahiran bahasa. Batasan ini juga memberikan pengertian bahwa membaca permulaan menunjuk pada hubungan grafis dengan proses kognitif.

Temple (1987:118 -- 26) mengemukakan bahwa menulis permulaan merupakan tindakan penggambaran/pendeskripsian pikiran atau gagasan dengan simbolsimbol tulisan. Coretan-coretan yang belum bermakna, sebenarnya bagi anak merupakan

paparan ide/gagasan yang disampaikan kepada orang lain. Selanjutnya dikemukakan bahwa tulisan anak/ siswa berkembang seiring proses membacanya. Implikasi pembelajaran bahasa adalah pembelajaran membaca diberikan bersamaan dengan pembelajaran menulis.

Tulisan anak pada awalnya merupakan coretan-coretan yang belum teratur, menurut orang yang sudah dapat menulis, namun pada dasarnya merupakan sesuatu yang sudah merupakan wujud ide/gagasannya. Implikasi dalam pembelajaran adalah bahwa dalam pembelajaran menulis dimulai dari membuat coretancoretan, setelah lentur tangannya diarahkan ke simbol-simbol bunyi yang sebenarnya.

Depdikbud (1991:6) mengemukakan bahwa secara garis besar, pembelajaran membaca dan menulis di sekolah dasar dibagi menjadi 2 tahap. Tahap pertama, yaitu membaca dan menulis permulaan diberikan di kelas 1 dan 2 (kelas rendah/awal). Sedangkan tahap kedua (setelah menguasai tahap 1), yaitu membaca dan menulis pemahaman diberikan di kelas 3 -- 6 (kelas tinggi).

Pembelajaran membaca dan menulis permulaan di kelas 1 , dibagi 
menjadi 2 tahap. Tahap pertama, yaitu membaca dan menulis tanpa buku, yang memerlukan waktu 8 -- 10 minggu. Sedangkan tahap kedua, membaca dan menulis dengan buku, yaitu setelah siswa menguasai membaca dan menulis tanpa buku. Tujuan utama pembelajaran membaca tanpa buku adalah agar siswa mempunyai kesiapan membaca 'reading readiness'. Tujuan utama menulis tanpa buku agar siswa mempunyai kelenturan motorik halus dalam menulis, terutama gerakan-gerakan tangannya.

Ruang lingkup pembelajaran membaca dan menulis tanpa buku di kelas 1 rendah/ awal berupa bernyanyi, memperkenalkan diri, mendengarkan cerita, bertanya jawab dengan guru, memperhatikan gambar, bercerita, membicarakan gambar, menemukan tanda bunyi. Sedangkan pembelajaran menulis tanpa buku berupa cara memegang pensil, cara duduk, cara membuka buku, gerakan tangan membuat garis lurus, garis lengkung, menulis di udara, menulis di pasir/di meja tanpa alat tulis, baru menulis di kertas/buku.

Ruang lingkup pembelajaran membaca dengan buku berupa membaca huruf, suku kata, kata, kalimat sederhana, wacana pendek. Pada tahap ini siswa sudah mulai diperkenalkan berbagai intonasi, beberapa tanda baca, dan beberapa ejaan. Sedangkan menulis dengan buku adalah membuat garis lurus di kertas, garis lengkung, menebalkan, mengeblat, meniru/menyalin huruf, kata, kalimat sederhana, serta melengkapi, menjodohkan, dan jawaban singkat.

Terdapat metode membaca dan menulis permulaan yang berlaku di sekolah dasar di Indonesia sejak merdeka, yakni secara umum sebagai berikut. (1) Metode yang paling tua adalah metode abjad, yakni pengenalan seluruh abjad, merangkai abjad/huruf menjadi kata, kalimat, dan wacana; (2) Metode bunyi/ eja, yakni diperkenalkan beberapa abjad/ huruf, huruf dirangkai menjadi kata de-ngan cara dieja bunyinya, menjadi kata, menjadi kalimat sederhana, dan menjadi wacana sederhana; Metode SAS, yakni diperkenalkan kalimat sederhana, diuraikan menjadi kata, menjadi suku kata, kata dan huruf, kemudian disintetiskan/dirangkai kembali menjadi suku kata, kata, kalimat; (4) Metode iqro (bahasa Arab), yakni pengenalan 
suku kata tanpa mengeja, suku kata dirangkai menjadi kata, menjadi kalimat, dan menjadi wacana pendek, kekuatan utama metode ini pada proses repetisi/ pengulangan dalam setiap pembelajaran.

Metode membaca dan menulis iqro modifikasi (MMIM) merupakan pengembangan dan kreasi dari metode membaca Al-Quran yang disusun oleh As'ad Humam (1990). Metode MMIM ini disusun dalam rangka menulis tesis di PPS IKIP Malang tahun 1997. Penelitian ini bertujuan mempercepat keterampilan membaca dan menulis permulaan siswa kelas 1 SDN Sumbersari 3 Malang, dengan menggunakan metode PTK. Hasil penelitian menunjukkan bahwa dalam waktu 3 bulan, $95 \%$ siswa terteliti sudah lancar membaca dan menulis permulaan.

Hasil penelitian Supriyadi (1997) yang berupa lampiran penelitian disusun dalam bentuk buku sederhana. Buku sederhana inilah yang kemudian disosialisasikan kepada guru-guru SD dan TK di Sumatera Selatan dan BangkaBelitung sejak tahun 2000-an sampai sekarang melalui kegiatan seminar/ pelatihan, PLPG di Unsri, LPMP
Sumsel, dan lembaga-lembaga lain. Berdasarkan informasi dari pengguna buku tersebut, siswa lebih cepat dan lancar membaca dan menulis. Selain itu, buku sederhana tersebut keefektifannya sudah beberapa kali dijadikan penelitian oleh beberapa mahasiswa S1 dan S2 Unsri dengan metodologi eksperimen dan PTK, hasil penelitian tersebut menunjukkan bahwa metode MMIM lebih efektif dibandingkan dengan metode lainnya.

Kekurangan dari draf/buku MMIM tersebut di antaranya adalah sebagai berikut. (1) Isi atau substansi materi yang berupa wacana masih fokus pada satu mata pelajaran Bahasa Indonesia, belum tematik dengan pelajaran lain seperti: IPA, IPS, dan Kesenian; (2) Belum dilengkapi dengan tujuan pembelajaran secara rinci; (3) Belum dilengkapi dengan petunjuk guru dan siswa dalam setiap kegiatan; (5) Gambargambar yang digunakan belum mencerminkan wacana dan belum dalam bentuk warna-warni; Penataan huruf dalam setiap satuan pembelajaran belum tertata secara artistik, dan (7) Evalusi yang digunakan belum tematik. 
Berdasarkan uraian yang dikemukakan pada bagian sebelumnya, perlu dikembangkan buku ajar/bahan ajar yang tematik, sistematis, mudah digunakan guru, menarik bagi siswa, serta mampu mempercepat belajar membaca dan menulis permulaan. Oleh karena itu, penelitian tentang pengembangan buku ajar membaca dan menulis permulaan dengan metode iqro modifikasi yang tematik perlu dilakukan.

Tujuan utama penelitian ini secara umum adalah terbentuknya buku ajar/ model pembelajaran membaca dan menulis permulaan dengan metode iqro modifikasi yang tematik Bahasa Indonesia, IPA, IPS, dan Kesenian untuk siswa kelas 1 sekolah dasar.

Secara khusus, penelitian ini bertujuan terbentuknya buku ajar yang mempunyai karakteristik sebagai berikut. (1) Menggunakan metode iqro modifikasi sebagai materi pokok membaca dan menulis; (2) Melengkapi adanya petunjuk bagi guru dan siswa dalam setiap kegiatan pembelajaran; (3) Memuat tujuan pembelajaran secara umum kegiatan pembelajaran; (4) Menggunakan wacana/ bacaan yang tematik IPA,
IPS, Kesenian; (5) Memuat kegiatan yang akan dilakukan siswa dan guru; (6) Memuat evaluasi formatif dalam setiap kegiatan pembelajaran; (7) Menggunakan gambar yang menarik; (8) Menggunakan huruf yang berkarakteristik menarik dan besar (font 22 -- 36).

Penelitian ini penting bagi terwujudnya percepatan dan kelancaran membaca dan menulis permulaan bagi siswa kelas 1 sekolah dasar/madrasah ibtidaiyah sehingga belajar membaca dan menulis permulaan kurang dari 1 semester. Di samping belajar membaca dan menulis dapat dipercepat, pemahaman siswa tentang konsep berpikir 'holistic', dapat dikembangkan melalui beberapa materi pelajaran yang diintegrasikan dalam suatu tema melalui pembelajaran tematik.

Buku/bahan ajar yang disusun dan dikembangkan dapat digunakan oleh guru sebagai buku suplemen pembelajaran di kelas $1 \mathrm{SD} / \mathrm{Ml}$ di seluruh Indonesia, terutama siswa yang belum lancar, bahkan bagi siapa pun yang ingin belajar membaca dan menulis permulaan dengan cepat. Buku ajar ini juga bisa digunakan untuk siswa paket $\mathrm{C}$ dan 
pemberantasan buta huruf. Selain itu buku/bahan ajar yang akan dihasilkan dapat digunakan oleh siapa pun yang ingin belajar membaca dan menulis permulaan tanpa bantuan guru, karena sistematika buku ini dirancang agar siswa belajar mandiri/CBSA. Selain itu, peneliti memperoleh hak cipta terhadap buku/bahan ajar yang telah dikembangkan melalui penelitian ini.

\section{B. Metode Penelitian}

\section{Jenis Penelitian}

Metode yang digunakan dalam penelitian ini adalah metode penelitian dan pengembangan (research and development). Borg \& Gall (1983:772) menyatakan bahwa penelitian dan pengembangan (R\&D) adalah suatu proses yang digunakan untuk mengembangkan dan memvalidasi produk pendidikan seperti: materi pembelajaran, buku teks, metode pembelajaran yang dilakukan dalam penelitian pengembangan. Sedangkan menurut Sugiono (2010:407) metode penelitian pengembangan adalah metode penelitian yang digunakan untuk menghasilkan produk tertentu dan menguji keefektifannya.

Berdasarkan dua pendapat di atas dapat disimpulkan bahwa penelitian pengembangan adalah proses yang digunakan untuk mengembangkan dan memvalidasi produk pendidikan dengan serangkaian langkah dalam suatu siklus, setiap langkah yang dilalui mengacu pada langkah sebelumnya sehingga akhirnya diperoleh suatu produk pendidikan yang baru. Produk pendidikan yang dimaksud adalah buku/bahan ajar membaca dan menulis permulaan dengan menggunakan metode iqro modifikasi tematik Bahasa Indonesia, IPA, IPS, Kesenian untuk siswa kelas 1 sekolah dasar.

\section{Langkah-langkah}

Penelitian

\section{Pengembangan}

Model penelitian dan pengembangan yang digunakan adalah pemkombinasian teori yang dikembangkan Gall \& Borg melalui Sugiono (2010:408 -- 427) dengan 10 langkah sebagai berikut.

1) Potensi dan masalah; Melakukan survei untuk memperoleh informasi, melalui kajian pustaka, pengamatan di sekolah dasar, wawancara dengan guru kelas 1 sekolah dasar. Hal ini dilakukan untuk mengetahui potensi masalah, analisis kebutuhan 
berupa minat, motivasi, permasalahan pembelajaran membaca dan menulis permulaan yang tematik dengan IPA, IPS, dan kesenian.

2) Mengumpulkan informasi; Setelah potensi masalah didapat, maka perlu dikumpulkan berbagai informasi yang dapat digunakan sebagai bahan untuk perencaan produk tertentu yang diharapkan dapat mengatasi masalah tersebut. Kegiatan pengumpulan informasi meliputi analisis kebutuhan, studi pustaka, pengamatan langsung, wawancara dengan piha-pihak terkait, misalnya guru, kepala sekolah, siswa, wali siswa.

3) Desain produk; Setelah informasi diperoleh kemudian melakukan perencanaan/ merancang berbagai kegiatan dan prosedur yang akan ditempuh dalam penelitian dan pengembangan produk. Desain produk diwujudkan dalam bentuk gambar atau bagan, uraian ringkas, petunjuk penggunaan produk, alat dan sarana yang digunakan sehingga memudahkan pihak lain untuk memahaminya. Desain produk/buku ajar didiskusikan bersama para praktisi, para ahli, dan piha-pihak yang terkait yang kemudian produk awal akan diuji validasi oleh para ahli.

4) Validasi desain; Validasi desain merupakan proses kegiatan untuk menilai apakah rancangan produk/ buku ajar secara rasional akan lebih efektif dari yang lama atau tidak. Dikatakan secara rasional karena validasi di sini masih bersifat penilaian berdasarkan pemikiran rasional, belum berdasarkan fakta di lapangan. Validasi produk/buku ajar dapat dilakukan dengan menghadirkan beberapa pakar atau tenaga ahli yang sudah berpengalaman untuk menilai produk/buku ajar baru yang dirancang tersebut. Setiap pakar diminta menilai desain/buku ajar tersebut sehingga dapat diketahui kelemahan dan kekuatannya.

5) Perbaikan desain; Setelah desain produk/buku ajar divalidasi melalui diskusi dengan para pakar dan ahli lainnya sehingga ditemukan kelemahan-kelemahannya.

Selanjutnya dari kelemahan tersebut diperbaiki (revisi) sehingga dihasilkan desain produk/buku ajar yang sudah direvisi. 
6) Uji coba produk; Dalam bidang pendidikan, desain produk/buku ajar sudah langsung dapat diuji coba setelah divalidasi dan direvisi. Selanjutnya desain produk/buku ajar tersebut dapat dibuat dalam bentuk prototipe. Prototipe inilah yang selanjutnya diuji coba. Uji coba tahap awal dilakukan dengan simulasi penggunaan produk/buku ajar. Setelah disimulasikan, maka dapat diujicobakan pada kelompok yang terbatas. Pengujicobaan dilakukan dengan tujuan untuk mendapatkan informasi apakah produk/buku ajar yang dikembangkan tersebut efektif dan efesien dibandingkan dengan yang lama.

7) Revisi produk; Langkah selanjutnya adalah revisi desain produk/buku ajar agar hasil pembelajaran dapat meningkat pada gradasi yang lebih tinggi. Setelah direvisi, maka perlu diujicobakan lagi pada kelas yang lebih luas.

8) Uji coba pemakaian; Selanjutnya produk/buku ajar diujicobakan pada kelas yang lebih luas. Kelas yang lebih luas di sini adalah sekolah-sekolah dasar yang berbeda-beda akreditasinya. Hal ini dimaksudkan untuk mendapatkan masukan yang lebih banyak agar menghasilkan produk/buku ajar yang mendekati sempurna.

9) Revisi produk; Revisi produk/buku ajar dilakukan apabila dalam pemakaian dalam lembaga/pengujian luas terdapat kekurangan dan kelemahan sehingga dapat digunakan untuk penyempurnaan produk/buku ajar. 10) Pembuatan produk masal; Bila produk telah dinyatakan efektif dalam beberapa pengujian, maka produk/ buku ajar tersebut dapat diproduksi masal. Dalam produksi masal ini, peneliti bekerja sama dengan percetakan/penerbit.

Dalam penelitian tahun ke-2 ini, dari 3 tahap/tahun yang direncanakan, keseluruhan langkah penelitian hanya sampai pada tahap ke-7, yaitu revisi produk setelah dilakukan uji coba terbatas. Sedangkan uji coba secara luas/ massal dan pengurusan HAKI direncanakan pada tahun ke-3.

Lokasi dan Subjek Uji Coba Terbatas 
Lokasi penelitian dilaksanakan di 2 sekolah dasar, 2 SDN 238 Negeri di Kota Palembang. Sekolah dasar tersebut adalah (1) Sekolah Dasar Negeri 238 akreditasi B, beralamat di Jln. Srijaya km 5,5, Kecamatan Sukarame Kota Palembang dan (2) Sekolah Dasar Negeri 24 (akreditasi B), Jalan Kapten Anwar Arsyad, Kelurahan Siring Agung, Kecamatan Ilir Barat 1, Kota Palembang.

Subjek penelitian ini adalah siswa kelas 1 sekolah dasar negeri yang masuk pada tahun ajaran baru 2017/2018. Jumlah subjek penelitian 4 orang siswa kelas 1 Sekolah Dasar Negeri 238 yang belum dapat membaca dan menulis dan 12 orang siswa kelas 1 SDN 24 Palembang. Sampel penelitian dipertimbangkan berdasarkan kemampuan membaca dan menulis yang sangat kurang, bahkan sama sekali.

\section{Teknik Pengumpulan Data dan Instrumen}

Teknik pengumpulan data yang digunakan dalam penelitian ini adalah tes dan nontes. Tes yang digunakan adalah tes hasil belajar, sedangkan nontes yang digunakan adalah angket (kuesioner), wawancara, dan observasi.
Tes

Tes adalah serentetan pertanyaan atau latihan serta alat lain yang digunakan untuk mengukur keterampilan, pengetahuan intelegensi, kemampuan atau bakat yang dimiliki oleh individu atau kelompok (Arikunto, 2006:150 --151). Tes dilaksanakan pada akhir pembelajaran. Tujuannya adalah untuk mengetahui hasil pembelajaran secara keseluruhan. Tes yang digunakan mengacu pada pendapat Djiwandono (1996:22) untuk mengetes bahasa digunakan tes tulis dan lisan. Tes tulis digunakan untuk mengetes kemampuan yang diuraikan di atas, sedangkan tes lisan digunakan untuk mengetes keterampilan berbicara.

Tes dalam penelitian ini digunakan untuk mengetahui kemampuan membaca dan menulis permulaan siswa kelas 1 yang menjadi subjek penelitian. Tes kemampuan membaca meliputi: membaca huruf tertentu, suku kata, kata, kalimat, dan wacana sederhana.Tes kemampuan menulis meliputi: menebalkan huruf, menyalin huruf/kata, menuliskan kata/ kalimat, melengkapi kata/kalimat, menjawab 
Pendas : Jurnal IImiah Pendidikan Dasar, ISSN Cetak : 2477-2143 ISSN Online : 2548-6950 Volume II Nomor 2, Desember 2017

pertanyaan pendek, kesemuanya tentang IPA dan IPS, serta syair lagu anak-anak.

\section{Nontes}

Angket/Kuesioner

Angket digunakan untuk menjaring analisis kebutuhan guru dan siswa dalam proses pembelajaran membaca dan menulis permulaan dengan tematik. Angket digunakan untuk mendapatkan informasi tentang perangkat yang digunakan, bahan yang digunakan dan yang dikehendaki, kendala yang dihadapi, media yang digunakan dan diharapkan, alat evaluasi yang digunakan. Angket juga digunakan dalam setiap tahap uji coba sehingga dapat diperoleh informasi mengenai segala hal berkaitan dengan produk/buku ajar tersebut.

\section{Observasi}

Observasi/pengamatan dalam penelitian ini memungkinkan peneliti mengamati perilaku dan kejadian yang terjadi dalam pelaksanaan pembelajaran di kelas. Pengamatan dilakukan untuk mengamati perilaku siswa dalam pembelajaran dengan menggunakanm produk/ buku ajar tersebu; Mengamati perangkat pembelajaran, mulai dari RPP, pelakasaan dan evaluasi pembelajaran sebelum dan sesudah menggunakan produk/buku ajar; Mengamati produk/buku ajar secara fisik, apa kekurangan sehingga penelitian ini menghasilkan produk/buku ajar yang efektif

\section{Wawancara}

Wawancara dilakukan secara mendalam baik secara formal maupun informal. Wawancara formal dilakukan dengan menggunakan polapola formal/ garis-garis pokok, topik atau masalah yang telah disiapkan. Sedangkan wawancara informal mengandung unsur spontanitas, santai, dan tanpa pola dan arah yang ditentukan.

\section{Teknik Analisis Data}

Data penelitian dianalisis secara kualitatif untuk mendeskripsikan buku ajar membaca dan menulis permulaan dengan metode iqro modifikasi tematik Bahasa Indonesia, IPA, IPS, dan Kesenian. Prosedur/langkah-langkah analisis data penelitian sebagai berikut.

1) Menganalisis data yang diperoleh dari hasil studi pendahuluan.

2) Membuat desain produk/buku ajar yang sesuai dengan hasil studi pendahuluan.

3) Memvalidasi desain buku ajar kepada para ahli berkaitan 
dengan kelayakan isi, kebahasaan, sajian, dan kegrafisan.

4) Merevisi desain buku ajar sesuai dengan saran para ahli.

5) Mengujicobakan desain buku ajar yang sudah direvisi secara terbatas.

6) Mendesain produk buku ajar setelah hasil uji coba

7) Membuat laporan.

\section{Hasil dan Pembahasan}

Hasil studi pendahuluan pada bagian ini mencakup hasil analisis terhadap kurikulum yang berlaku, hasil analisis terhadap buku pelajaran yang ada selama ini, dan hasil analisis terhadap analisis kebutuhan menurut pendapat guru dan kepala sekolah.

\section{Hasil Analisis Kurikulum}

Kurkulum yang digunakan sebagai acuan dalam analisis ini adalah Kurikulum 2013. Walaupun saat ini kurikulum itu belum diberlakukan secara menyeluruh, tetapi pada tahun-tahun berikutnya seluruh sekolah harus mengimplementasikan Kurikulum 2013.

$$
\text { Hasil analisis terhadap }
$$
kurikulum 2013 dapat dijelaskan sebagai berikut.
1) Untuk kelas I -- III , Kompetensi IPA dan IPS diintegrasikan ke dalam konten mata pelajaran lain (Agama dan Budi Pekerti sampai Pendidikan Jasmani dan Kesehatan). Untuk kelas IV -- VI KD IPA dan IPS berdiri sendiri kemudian diintegrasikan ke dalam tema-tema yang ada.

2) Beban belajar bagi siswa untuk kelas I: 30; kelas II: 32; kelas III: 34 jam pelajaran per minggu; bagi kelas IV -- VI: 36 jam pelajaran per minggu. Lama setiap jam pelajaran adalah 35 menit.

3) Pendekatan yang digunakan di SD/MI adalah pendekatan tematik integratif dari kelas I sampai kelas VI.

4) Tema yang dipilih berkaitan dengan alam dan kehidupan manusia yang memberi makna pada semua mata pelajaran (kelas I -- III kecuali IPA dan IPS, kelas IV -- VI termasuk IPA dan IPS).

\section{Hasil Analisis terhadap Buku Teks}

Ada beberapa buku teks yang dianalisis sebagai bagian dari studi awal pada penelitian ini. Pertama, buku yang beredar di pasaran dan digunakan sebagai bahan ajar oleh guru di Palembang. Kedua, buku 
yang disusun oleh Pusat Kurikulum dan Perbukuan yang digunakan secara nasional.

Ada tiga buku yang beredar di lapangan/pasaran yang digunakan oleh guru di Palembang.

1) Panduan Belajar Tematik SD untuk Kelas 1 Semester 1 oleh Hilda Karli dan Margaretha Sri Yuliariatinigsih diterbitkan oleh Penerbit Erlangga, 2007.

a) Tema yang ada: hewan dan tumbuhan, kesehatan, pekerjaan, hiburan, kejadian sehari-hari, dan pengalaman

b) Setiap tema mencakup mata pelajaran: bahasa Indonesia, matematika, pengatahuan alam, pengetahuan sosial, dan seni budaya.

c) Buku ini dicetak dengan huruf yang jelas dan ukuran yang mudah dibaca oleh anak-anak serta dilengkapi dengan gambar/ilustrasi berwarna.

d) Buku ini cocok untuk anak yang sudah dapat membaca dan menulis dengan lancar bila dilihat dari tugas-tugas dan petunjuk untuk siswa.

2) Inilah Bahasa Indonesiaku untuk Kelas I SD dan MI oleh Karsidi, diterbitkan oleh Tiga Serangkai Pustaka Mandiri, tahun 2012.

a) Pokok bahasan: diri sendiri, keluargaku, pengalaman, budi pekerti,

pekerjaan, kegiatan,lingkungan, kegemaran, permainan, dan kesehatan (masing-masing 5 pokok bahasan semester 1 dan 5 semester 2).

b) Tidak ada mata pelajaran lain secara eksplisit disebutkan, tetapi ada beberapa materi bacaan yang cocok untuk mata pelajaran IPA dan IPS.

c) Buku ini dicetak dengan huruf yang jelas dan mudah dilihat oleh anak-anak, dilengkapi dengan gambar/ ilustrasi berwarna.

d) Ada aspek membaca dan menulis permulaan.

3) Membaca dan Menulis Permulaan dengan Metode lqro untuk TK dan Kelas ISD/MI oleh Supriyadi, dicetak sendiri, tidak diterbitkan oleh penerbit resmi.

a) Tidak ada tema yang dipaparkan. Semata-mata untuk berlatih membaca dan menulis permulaan, dilengkapi dengan wacana pendek berup 
lagu anak-anak dan juga dongeng.

b) Huruf yang digunakan cukup jelas dan ukurannya dapat dengan mudah dibaca oleh anak. Dilengkapi dengan gambar/ilustrasi tidak berwarna.

c) Buku yang sesuai dengan Kurikulum 2013 yang disusun oleh Pusat Kurikulum dan Perbukuan.

4) Ada 4 tema: diriku, kegemaranku, kegiatanku, dan keluargaku.

5) Tema diriku memiliki 4 subtema: aku dan teman baru, tubuhku, aku merawat tubuhku, dan aku istimewa.

6) Secara grafika bagus, dengan jenis dan ukuran huruf yang mudah dibaca oleh anak-anak, dilengkapi dengan gambar dan ilustrasi berwarna.

7) Setiap tema dikemas dalam buku tersendiri.

8) Buku ini cocok untuk siswa yang sudah lancar membaca dan menulis permulaan, sedangkan siswa yang belum lancar sangat kesulitan.

Dari tiga buah buku yang digunakan oleh para guru dapat dikatakan bahwa tidak ada buku pelajaran membaca dan menulis permulaan yang tematik sekaligus mengikuti prinsip-prinsip pembelajaran membaca-menulis permulaan. Ada buku yang sudah tematik, tetapi kurang cocok untuk siswa yang baru belajar membaca dan menulis. Buku semacam itu cocok untuk siswa yang sudah lancar membaca. Di samping itu, buku yang memenuhi prinsip belajar membaca dan menulis permulaan, tetapi tidak bersifat tematik. Ada juga buku yang secara eksplisit cocok untuk satu mata pelajaran, yaitu bahasa Indonesia.

Adapun buku siswa tentang Puskurbuk dapat dikatakan bahwa buku itu lebih sesuai untuk siswa yang sudah lancar membaca. Hal ini dapat dilihat dari petunjuk-petunjuk yang digunakan, contoh kata-kata yang ada, dan latihan-latihan yang harus dikerjakan oleh siswa.

\section{Hasil Wawancara dan Angket}

Wawancara terhadap beberapa orang guru SD dilakukan untuk mendapatkan informasi tentang buku seperti apa yang diperlukan guru sebagai buku pelengkap dalam implementasi kurikulum 2013. Hasil wawancara itu diringkaskan sementara sebagai berikut.

1) Apabila pada 2014 mendatang semua sekolah harus 
melaksanakan kurikulum 2013, beberapa guru menyatakan belum siap. Kesulitannya adalah pada tidak adanya bahan ajar yang mudah digunakan oleh guru yang sesuai dengan karakteristik siswa di Palembang.

2) Buku siswa dan buku guru yang menjadi sumber belajar utama yang disusun dari pusat kurikulum dan perbukuan menurut pandangan guru terlalu "tinggi" bagi sebagian besar siswa SD di Palembang. Buku itu sesuai untuk anak-anak yang sudah lancar membaca dan menulis permulaan sejak mereka masuk pada kelas I.

3) Yang diperlukan/dibutuhkan adalah buku ajar yang dapat membantu siswa melatih membaca dan menulis permulaan dari siswa belum dapat membaca sama sekali. Buku seperti itu dapat menjadi bahan ajar "pendahuluan" sebelum siswa dapat menggunakan buku ajar yang disediakan oleh Puskurbuk Kementerian Pendidikan dan Kebudayaan. Buku pelajaran membaca dan menulis permulaan yang merupakan pendahuluan itu diharapkan dapat menjembatani penggunaan buku ajar dari puskurbuk tersebut.

4) Buku ajar seperti itu menurut pandangan guru harus bersifat tematik integratif juga agar guru dan siswa terbiasa dengan penerapan pendekatan itu. Buku itu dilengkapi dengan latihan-latihan yang lebih banyak dalam membaca dan menulis permulaan, seperti mengenal huruf, menuliskan huruf, membaca suku kata dan menuliskannya, membaca kata, kalimat, dan wacana pendek, serta menuliskannya.

5) Buku ajar juga diharapkan dilengkapi dengan panduan untuk guru secara rinci berupa tahaptahap melatihkannya kepada siswa dan bagaimana mengecek/menilai kemajuan siswa.

6) Secara grafika, buku ajar dicetak dengan jenis dan ukuran huruf yang sesuai untuk anak kelas I SD, ada gambar/ilustrasi yang berwarna, ketebalan buku tidak melebihi 60 halaman agar dengan mudah dapat dibawa oleh siswa sehingga latihan dapat lebih sering dilakukan, baik di sekolah maupun di rumah.

Hasil Pengembangan 
Sampai tahap ini hasil pengembangan buku ajar dapat dijelaskan sebagai berikut. Tema dan subtema yang dirancang untuk buku ini adalah seperti pada tabel berikut.

Tabel 1. Rencana Tema dan Subtema

\begin{tabular}{|l|l|l|}
\hline No. & Tema & Subtema \\
\hline 1 & \multirow{2}{*}{ Diriku } & Namaku \\
\cline { 3 - 3 } & & Tubuhku \\
\hline 2 & \multirow{2}{*}{ Keluargaku } & Ayah \\
\cline { 3 - 3 } & & Ibu \\
\cline { 3 - 3 } & & Kakak-adik \\
\hline 3 & \multirow{2}{*}{ Temanku } & Nama temanku \\
\cline { 3 - 3 } & & $\begin{array}{l}\text { Kesukaan } \\
\text { temanku }\end{array}$ \\
\hline 4 & \multirow{2}{*}{$\begin{array}{l}\text { Benda- } \\
\text { benda }\end{array}$} & $\begin{array}{l}\text { Peralatan rumah } \\
\text { Benda } \\
\text { rumah }\end{array}$ \\
\hline 5 & \multirow{2}{*}{ Hewan } & Hewan piaraan \\
\cline { 3 - 3 } & & $\begin{array}{l}\text { Hewan } \\
\text { piaraan }\end{array}$ \\
\hline 6 & \multirow{2}{*}{ Tanaman } & Bunga \\
\cline { 3 - 3 } & & Buah \\
\hline
\end{tabular}

Perencanaan Kerangka Buku

Rancangan isi buku dapat dikerangkakan seperti pada tabel berikut.

\begin{tabular}{|c|c|c|}
\hline No & $\begin{array}{l}\text { Tema/ } \\
\text { Subtema }\end{array}$ & Kegiatan \\
\hline 1. & $\begin{array}{l}\text { Diriku/ } \\
\text { Namaku }\end{array}$ & $\begin{array}{l}\text { Membaca: } \\
\text { Mengenalkan } \\
\text { huruf vokal a, i, } \\
\text { konsonan n, } \\
\text { dan m. a, , } \\
\text { ana, nana, } \\
\text { nani, mama, } \\
\text { mimi } \\
\text { Menulis: } \\
\text { Membuat garis } \\
\text { tegak, } \\
\text { condong }\end{array}$ \\
\hline
\end{tabular}

\begin{tabular}{|c|c|c|}
\hline No & $\begin{array}{l}\text { Tema/ } \\
\text { Subtema }\end{array}$ & Kegiatan \\
\hline & & $\begin{array}{l}\text { O Menebalkan } \\
\text { huruf }\end{array}$ \\
\hline 2. & $\begin{array}{l}\text { Temanku/ } \\
\text { Nama } \\
\text { Temanku }\end{array}$ & $\begin{array}{l}\text { Membaca: } \\
\text { o Pengenalan } \\
\text { huruf vocal u } \\
\text { dan konsonan } \\
\text { k } \\
\text { o Memantapkan } \\
\text { huruf konsonan } \\
\text { k, aku ana, } \\
\text { namaku nana, } \\
\text { aku ani, aku } \\
\text { mimi anis: } \\
\text { Menulis } \\
\text { O Menebalkan } \\
\text { huruf } \\
\text { O Menjiplak } \\
\text { O Menirukan } \\
\text { bentuk huruf }\end{array}$ \\
\hline 3. & $\begin{array}{l}\text { Keluarga/ } \\
\text { Keluargaku }\end{array}$ & $\begin{array}{l}\text { Membaca } \\
\text { O Pengenalan } \\
\text { huruf vokal o } \\
\text { dan kononan b } \\
\text { O Memantapkan } \\
\text { pengenalan } \\
\text { huruf vocal e } \\
\text { dan konsonan } \\
\text { c, d, s, y, p, t, } \\
\text { g, j, r, l, w, h, } \\
\text { Mengenalkan } \\
\text { huruf dobel ny, } \\
\text { ng, wan, man, } \\
\text { kan, pak, ran, } \\
\text { hor, } \\
\text { Mengenalkan } \\
\text { kata-kata } \\
\text { bagian tubuh } \\
\text { dengan dua } \\
\text { suku kata } \\
\text { terbuka } \\
\text { Mengenalkan } \\
\text { kata-kata } \\
\text { bagian tubuh } \\
\text { dengan tiga } \\
\text { suku kata } \\
\text { terbuka }\end{array}$ \\
\hline
\end{tabular}




\begin{tabular}{|c|c|c|}
\hline No & $\begin{array}{l}\text { Tema/ } \\
\text { Subtema }\end{array}$ & Kegiatan \\
\hline & & $\begin{array}{l}\text { O Mengenalkan } \\
\text { kalimat pendek } \\
\text { Menulis: } \\
\text { o Menebalkan } \\
\text { huruf } \\
\text { O Menirukan } \\
\text { huruf dan suku } \\
\text { kata } \\
\text { O Menirukan } \\
\text { suku kata dan } \\
\text { kata } \\
\text { - Menulis huruf } \\
\text { vokal }\end{array}$ \\
\hline 4. & Diriku & $\begin{array}{l}\text { Membaca } \\
\circ \text { Mengenalkan } \\
\text { huruf mati pada } \\
\text { akhir kata } \\
\circ \text { Mengenalkan } \\
\text { kata bagian } \\
\text { tubuh } \\
\circ \text { Mengenalkan } \\
\text { kalimat pendek } \\
\text { Menulis } \\
\circ \text { Menirukan } \\
\text { suku kata dan } \\
\text { kata } \\
\circ \text { Menulis huruf } \\
\text { dan suku kata }\end{array}$ \\
\hline 5. & Keluargaku & $\begin{array}{l}\text { Membaca } \\
\text { o Mengenalkan } \\
\text { kata ibu, } \\
\text { mama, mami, } \\
\text { umi, papa, } \\
\text { papi, abi, dedi } \\
\text { O Mengenalkan } \\
\text { kata bibi } \\
\text { O Mengenalkan } \\
\text { kalimat pendek } \\
\text { Menulis } \\
\text { O Menirukan kata } \\
\text { dan kalimat } \\
\text { O Menulis suku } \\
\text { kata dan kata }\end{array}$ \\
\hline 6. & Benda- & Membaca \\
\hline
\end{tabular}

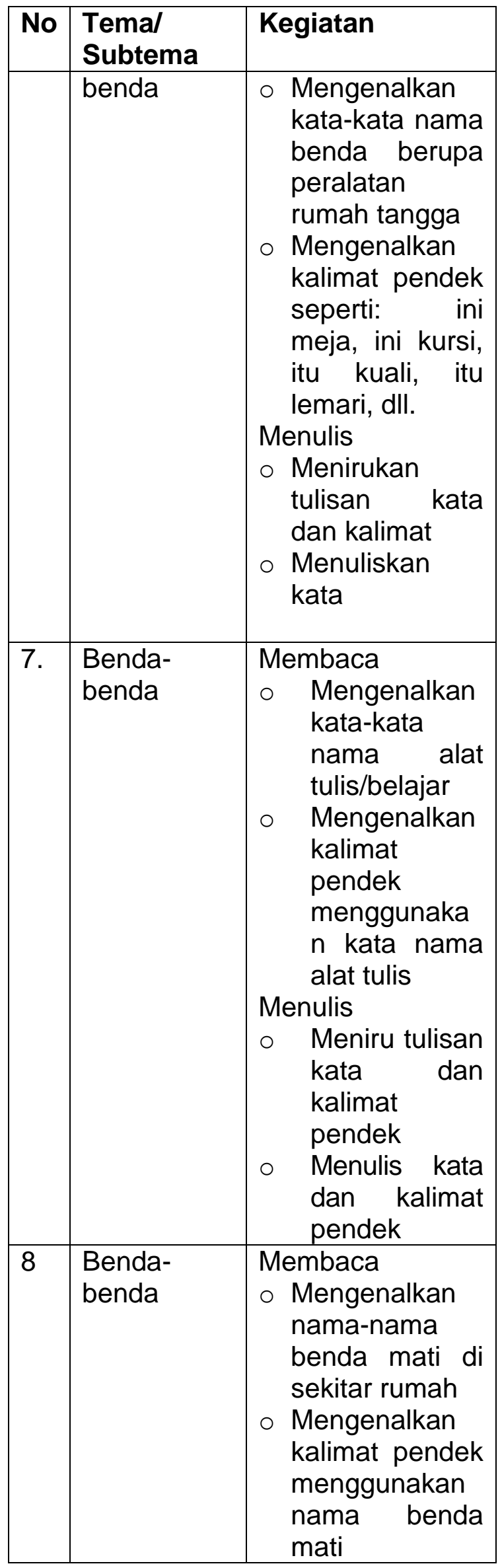




\begin{tabular}{|c|c|c|}
\hline No & $\begin{array}{l}\text { Tema/ } \\
\text { Subtema }\end{array}$ & Kegiatan \\
\hline & & $\begin{array}{ll}\text { Menulis } \\
\circ \text { Menuliskan } \\
\text { kata } \\
\circ \text { Menuliskan } \\
\text { kalimat }\end{array}$ \\
\hline 9 & $\begin{array}{l}\text { Lagu-lagu } \\
\text { Kesukaanku }\end{array}$ & 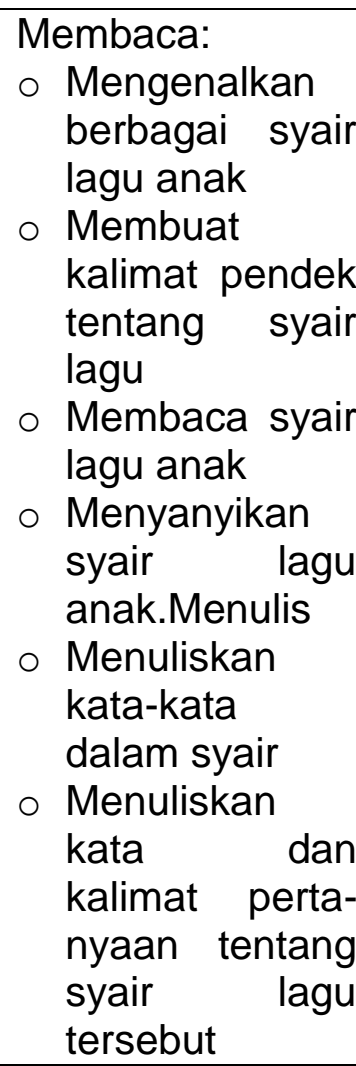 \\
\hline 10 & Hewan & $\begin{array}{l}\text { Membaca: } \\
\text { o Mengenalkan } \\
\text { nama hewan } \\
\text { yang tidak } \\
\text { dipelihara } \\
\text { o Membaca } \\
\text { kalimat tentang } \\
\text { hewan dan } \\
\text { tempat hidup- } \\
\text { nya } \\
\text { - Membaca } \\
\text { wacana } \\
\text { berbagai cerita/ } \\
\text { dongeng } \\
\text { tentang hewan } \\
\text { Menulis } \\
\text { o Menulis kata } \\
\text { dan kalimat } \\
\text { Menirukan }\end{array}$ \\
\hline
\end{tabular}

\begin{tabular}{|c|c|c|}
\hline \multirow[t]{2}{*}{ No } & $\begin{array}{l}\text { Tema/ } \\
\text { Subtema }\end{array}$ & Kegiatan \\
\hline & & $\begin{array}{l}\text { tulisan wacana } \\
\text { pendek }\end{array}$ \\
\hline 11 & Tanaman & $\begin{array}{l}\text { Membaca } \\
\text { o Mengenalkan } \\
\text { nama tanaman } \\
\text { dan bagiannya } \\
\text { \% Membaca } \\
\text { kalimat tentang } \\
\text { tanaman } \\
\text { O Membaca } \\
\text { wacana } \\
\text { pendek tentang } \\
\text { ciri-ciri } \\
\text { tanaman } \\
\text { Menyanyikan } \\
\text { lagu "Lihat } \\
\text { Kebunku". } \\
\text { Menulis } \\
\text { o Menuliskan } \\
\text { kata dan } \\
\text { kalimat } \\
\text { Oenulis } \\
\text { wacana } \\
\text { pendek }\end{array}$ \\
\hline
\end{tabular}

\section{Penyusunan Draf Awal Buku}

Draf awal buku yang berhasil dibuat dapat dideskripsikan sebagai berikut. Buku ini terdiri atas 50 halaman, menggunakan kertas ukuran kertaqs A-4. Huruf yang digunakan adalah Calibri dan Arial ukuran 22 -- 36. Buku ini juga menggunakan gambar/ilustrasi berwarna dengan kertas mengkilat. Sampul dirancang memberikan informasi bahwa buku ini adalah buku suplemen Kurikulum-13 sekolah dasar kelas 1, yang dapat juga 
digunakan untuk Taman KanakKanak.

\section{Penutup}

Berdasarkan hasil penelitian dapat disimpulkan hal-hal sebagai berikut.

1) Hasil analisis terhadap kurikulum 2013 menunjukkan bahwa diperlukan buku ajar yang sesuai dengan pendekatan tematik integratif untuk melatih membaca dan menulis permulaan di kelas I SD.

2) Hasil analisis terhadap buku-buku yang digunakan oleh guru selama ini menunjukkan bahwa lebih banyak buku yang belum sesuai dengan pendekatan tematik integratif. Sudah ada buku yang bersifat tematik, tetapi belum terintegrasi secara memadai. Bahkan, masih ada buku yang secara eksplisit merupakan buku mata pelajaran bahasa Indonesia, atau lebih spesifik lagi buku membaca dan menulis permulaan.

3) Hasil wawancara dan angket menunjukkan bahwa guru-guru memerlukan buku yang mudah digunakan, dapat mempercepat kemampuan membaca dan menulis permulaan, tetapi tetap berpedoman pada kurikulum 2013, yaitu menggunakan pendekatan tematik integratif.

4) Untuk menyusun buku ajar yang sesuai dengan keperluan itu, telah tersusun tema -- subtema, kerangka buku, gambar-gambar yang sesuai dengan konteks kata, kalimat, dan wacana, warna-warni menarik, petunjuk umum, dan evaluasi. Tahap berikutnya akan dilakukan uji coba secara luas/massal di beberapa sekolah dasar di Sumatera Selatan, kemudian revisi final yang kemudian diproses HAKI.

Disarankan kepada guru-guru hendaknya dapat memilih buku secara objektif yang sesuai dengan Kurikulum 2013 sebagai buku pelengkap terhdap buku ajar yang telah disusun oleh Pusat Kurikulum dan Perbukuan.

\section{Daftar Pustaka}

Arijani, Risah. (2013). Meningkatkan Kemampuan Membaca Permulaan Menggunakan Media Snader Game. Jurnal Pendidikan Anak, vol II, edisi 2, Desember 2013. Diases, 16 Agustus 2017. 
Pendas : Jurnal IImiah Pendidikan Dasar, ISSN Cetak : 2477-2143 ISSN Online : 2548-6950 Volume II Nomor 2, Desember 2017

Arikunto, Suharsimi. (2006). Prosedur Penelitian Suatu Pendekatan Praktik. Jakarta: Rineka Cipta.

Broughton, et al. (1978). Teaching English as a Foreign Language. London: Routlege, Kegan Paul.

Depdikbud. (1991/1992). Pengajaran Membaca dan Menulis Kelas 1 dan 2 di Sekolah Dasar. Dirpendas. P2MSDK. Jakarta.

Depdiknas. (2006). Pembelajaran Tematik Kelas Awal Sekolah Dasar. Jakarta: Pusat Kurikulum dan Pengembangan Departemen Pendidikan Nasional.

Djiwandono, M. Sunardi. (1996). Tes Bahasa dalam Pengajaran. Institut Teknologi Bandung: Bandung.

Downing, John \& Leong C.K. (1982). Psychology Desaign of Reading. New York: McMillan Publishing. Inc.

Gall, D. Meredith, Joyce P. Gall and W.R. Borg. (1983). Education Research: An Introduction. Boston, New York, USA.

Humam, As'ad. (1990). Buku lqro; Cara Cepat Belajar Membaca Alquran. Jilid 1-- 6. Yogyakarta: Tim Tadarus AMM.
Rahmawati.

(2017).

Strategi Pembelajaran Membaca dan Menulis Permulaan Melalui Media Kata Bergambar. Jurnal SAP vol 1 no. 3, April 2017. Diases 2 Agustus 2017.

Sugiono. (2010). Metode Penelitian Pendidikan Pendekatan Kuantitatif dan R\&D. Bandung: Alfabeta.

Supriyadi. (1997). Pembelajaran Membaca dan Menulis Permulaan dengan Metode lqro bagi Siswa Kelas Awal Sekolah Dasar. Tesis. Belum diterbitkan. Malang: PPS IKIP Malang.

Temple, Charles. Et al. (1987). The Beginning of Writing. Second Edition. Boston: Allyn and Bacon Inc.

Undang-Undang Republik Indonesia No. 23 tahun 2002 tentang Perlindungan Anak. 2002. Jakarta: Tamita Utama.

Undang-Undang Republik Indonesia No. 20 tahun 2003 Tentang Sistem Pendidikan Nasional. 2003. Jakarta: Tamita Utama.

Undang-Undang Republik Indonesia no. 14 tahun 2005 tentang guru dan Dosen. 2006. Jakarta: Tamita Utama 